\title{
Clinical conditions and history of illness among terminal chronic kidney disease patients
}

\author{
Titiek Hidayati ${ }^{1}$, Arya Adiningrat ${ }^{2}$, Akrom $^{3}$ \\ ${ }^{1}$ Public Health and Family medicine, Medical and Health Science Faculty, Universitas Muhammadiyah Yogyakarta, \\ Indonesia \\ ${ }^{2}$ Molecular Medicine and Therapy research, Medical and Health Science, Universitas Muhammadiyah Yogyakarta, \\ Indonesia \\ ${ }^{3}$ Pharmacology and Clinical Pharmacy Department, Pharmacy Faculty, Universitas Ahmad Dahlan, Indonesia
}

\begin{abstract}
Article Info
Article history:

Received Aug 27, 2019

Revised Oct 20, 2019

Accepted Nov 21, 2019

\section{Keywords:}

Case-control

ESRD

Hyperglycemia

Hypertriglyceridemia

Hypertension

ABSTRACT

End-stage renal disease (ESRD) is one of the public health problems in Indonesia. This study aimed to determine the clinical condition of premorbid and the incidence of ESRD. The study design is a case-control. The number of volunteers involved in this study was 100 patients. The cases were ESRD patients who were determined by the criteria of Pernefri and the controls were patients from the same hospital who were not ESRD by the requirements of ESRD Pernefri. Inclusion criteria of the study sample were ESRD sufferers need routine hemodialysis and doctor's diagnosis supported by laboratory data, 15-75 years old and willing to fill out inform consent. Exclusion criteria for the study sample were patients with congenital kidney disease, Have a history of kidney transplants, and mental disorder. We collected demographic data, and patient's clinical and drug history from medical records. Chi-square analysis with $2 \times 2$ tables and the Fisher's exact test were used to determine the relationship of clinical conditions and history of disease with the incidence of ESRD. The results showed that anemia, hyperglycemia, and hypertriglyceridemia were related to the prevalence of ESRD. History of hypertension, diabetes mellitus, dyslipidemia, and family history of ESRD are associated with an increased incidence of ESRD.
\end{abstract}

Copyright (C) 2019 Institute of Advanced Engineering and Science. All rights reserved.

\section{Corresponding Author:}

Akrom,

Pharmacology and Clinical Pharmacy Department, Pharmacy Faculty,

Universitas Ahmad Dahlan, Yogyakarta, Indonesia.

Email: akrom@pharm.uad.ac.id

\section{INTRODUCTION}

End-stage renal disease (ESRD) now and in the future is world health problems including in Indonesia [1-2]. Terminal chronic renal failure occurs when the glomerular filtration rate (LFG) is less than 15 $\mathrm{ml} /$ minute $/ 1.73 \mathrm{~m} 2$ for three months or more or creatinine clearance $<5 \mathrm{ml} /$ minute and serum creatinine levels are more than or equal to $10 \mathrm{mg} / \mathrm{mL}$ [3-5]. In Indonesia, the incidence and prevalence of ESRD are at 100-150 and 200-250 per 1 million population per year. It was determined that there were more than 7,000 ESRD patients in Indonesia [6-8]. The mortality rate of patients with ESRD 5-10x is not ESRD. The mortality rate of ESRD patients in the first year of illness reached $20 \%$ and increased to $60 \%$ in the fifth year [9-12]. In 2030 ESRD is estimated to contribute $30 \%$ to the cause of death in the world $[1,11,13]$. Besides the increasing incidence, prevalence, and mortality rate of ESRD, what needs to be considered is the significant cost of care for ESRD patients [14-15]. ESRD does not only cause physical, economic and psychological damage to sufferers but also a burden on families, as well as the state so that efforts are preventive and promotive [7, 16]. In line with the results of other studies, previous reseracher [17] reported 
that nearly $50 \%$ of ESRD patients who do hemodialysis at PKU Muhammadiyah Yogyakarta hospital have a low quality of life $[14,18]$.

Until now, treatment or treatment of patients with ESRD rests on two actions, namely kidney transplantation or undergoing dialysis to replace permanently damaged kidney function [19]. Both kidney transplantation and hemodialysis are actions that require high costs, and the results are not satisfactory. Due to the increasing number of ESRD sufferers in Indonesia, it is necessary to develop a preventive and promotive program in the field of nephrology. Identifying premorbid clinical risk factors and other biological factors as a basis for clinical decision making should be identified [6, 20-22]. However, not all ESRD risk factors in Indonesia have yet to be identified. Therefore this research needs to be done in Indonesia. The purpose of the study, in general, was to determine the relationship of premorbid clinical conditions with the incidence of ESRD.

\section{RESEARCH METHOD}

\subsection{Type and design of the study}

This study was an observational analytic study with a case-controlled design. ESRD patients as a case group, while non ESRD volunteers who are by or without smoking as a control. Data gathered at PKU Muhammadiyah Yogyakarta Hospital, Bantul public Hospital, Sleman public Hospital, and Panti Rapih Hospital in Special Region of Yogyakarta (SRY).

\subsection{Research subject}

The population was patients diagnosed with terminal chronic renal failure for no more than three months, with diagnostic criteria namely creatinine clearance $<5 \mathrm{ml} /$ minute or blood serum creatinine level greater or equal to $10 \mathrm{mg} / \mathrm{dl}$ which can be known from medical records and requires continuous hemodialysis. Inclusion criteria for research subjects: Indonesians (Javanese, Sundanese, Malay); ages 15-65 years old; willing to participate in research by filling out and signing the agreement and cooperative statement sheets; and new ESRD patients namely establishing a diagnosis of ESRD in patients with or less than three months. Research subjects who have been selected through inclusion criteria will be excluded from the study subjects if: have congenital kidney disease, kidney transplant history, mental illness. The minimum number of samples needed for the case is 44 people. With a comparison of between cases and control is 1:2, the number of controls group is 88 patients. The minimum number of research subjects is 132 people. Sampling is done by consecutive random sampling.

\subsection{Tools and materials.}

The tools and materials in this study include equipment for primary data collection (questionnaires), secondary data collection forms, chemicals, and glassware.

\subsection{Operational variables and definitions of research}

Independent variables were gender, body weight (BW), age and smoking activity as well as blood cotinine levels. The dependent variable is ESRD. Terminal chronic kidney disease is a persistent (more than three months) kidney function disorder and requires a kidney transplant or routine dialysis to replace kidney function; kidney abnormalities are measured by a decrease in GFR $<5 \mathrm{ml} /$ minute or serum creatinine levels greater than or equal to $10 \mathrm{mg} / \mathrm{dL}$. YES if the respondent meets laboratory criteria or requires a kidney transplant or undergoes hemodialysis. NO, if the respondent does not meet laboratory criteria or needs a kidney transplant or undergoing hemodialysis.

\subsection{Collection data procedure}

Measuring instruments used in this study include (i) Questionnaire, used to obtain primary data demographic characteristics and smoking habits of respondents. (ii) The data collection form is used to collect secondary data taken from medical record books or patient status which include name, age, gender, previous pain and medication diagnosis data, laboratory data and patient clinical manifestations.

\subsection{Operational limitations}

In general, data collection in this study was carried out by interviews, observation, and direct measurements. Primary data about ESRD pain history and smoking history were collected by structured interviews with guided questionnaires. Original data about the characteristics and clinical manifestations of the subject is obtained by direct measurement. Secondary data on demographic characteristics and pain history and treatment of research subjects were taken from medical records and supplemented by interviews with assisted forms of data collection and questionnaires. 
The implementation phase includes activities in the field as well as in the laboratory as follows: (i) Primary data collection in the sample by interview using a questionnaire provides for the identity of the respondent, socio-economic, smoking behavior, disease data obtained from the patient's medical record and other related data with research variables. Subjects/volunteers who have fasted 8-12 hours measured blood pressure, waist circumference, body weight, and height for the determination of body mass index (BMI). Prospective subjects who met the inclusion criteria have explained the purpose of the study and were asked to fill out an informed consent sheet as proof of the participation of the subjects in the research and fill out the questionnaire. The case/control subjects were taken for $5 \mathrm{ml}$ of blood from the anterior cubital median vein. $3 \mathrm{ml}$ of blood was centrifuged at $3000 \mathrm{~g}$ for 15 minutes. The serum is used to examine creatinine, BUN, random blood glucose, triglyceride, cholesterol levels, and other examinations. Examination of creatinine and laboratory levels was carried out by the spectrophotometer method, as was done by previous researchers [23].

\subsection{Data analysis}

Chi-square analysis with $2 \times 2$ or $3 \times 2$ tables with Fisher's exact test was used to assess the relationship of clinical or biological conditions and illness history to the incidence of ESRD.

\subsection{Research ethics}

Because it involves human respondents, it explained to all prospective respondents about the purpose and objectives of the research, the benefits and expected uses and the consequences of the respondent (informed consent), in addition to the management of ethical clearance (No KEPK/847/EC).

\section{RESULTS AND DISCUSSIONS}

\subsection{Overview of respondents}

The research subjects consisted of 53 ESRD patients as the cases and 106 non ESRD patients as the controls, originating from 4 hospitals in Special Region of Yogyakarta (SRY), namely PKU Muhammadiyah Yogyakarta private Hospital, Sleman regional public Hospital, and Bantul regional public Hospital. The demographic conditions of research subjects according to age group, sex, type of work, and level of education as well as those responsible for medical expenses are presented in Table 1.

Table 1. The demographic characteristics of ESRD patients in the Special Region of Yogyakarta.

\begin{tabular}{|c|c|c|c|c|c|c|}
\hline \multirow{2}{*}{ No } & & \multirow{2}{*}{ Respondents characteristics } & \multicolumn{2}{|c|}{ Respondent status } & \multirow{2}{*}{ Total } & \multirow{2}{*}{$\mathrm{P}$} \\
\hline & & & Cases (CKD) & Control & & \\
\hline \multirow{4}{*}{1} & \multirow{4}{*}{ Hospital } & PKU Yogyakarta hospital & $19(33.3 \%)$ & $38(66.7 \%)$ & $57(100 \%)$ & \multirow{4}{*}{1} \\
\hline & & PKU Gamping hospital & $6(33.3 \%)$ & $12(66.7 \%)$ & $18(100 \%)$ & \\
\hline & & Bantul regional hospital & $25(33.3 \%)$ & $50(66.7 \%)$ & $75(100 \%)$ & \\
\hline & & Sleman regional hospital & $3(33.3 \%)$ & $6(66.7 \%)$ & $9(100 \%)$ & \\
\hline \multirow{3}{*}{2} & \multirow{2}{*}{ Sex } & Male & $35(33.3 \%)$ & $70(66.7 \%)$ & $105(100 \%)$ & \multirow{2}{*}{0.568} \\
\hline & & Female & $18(33.3 \%)$ & $36(66.7 \%)$ & $54(100 \%)$ & \\
\hline & \multirow{4}{*}{ Age group } & 16-30 year & $5(31.2 \%)$ & $11(68.8 \%)$ & $16(100 \%)$ & \multirow{4}{*}{0.998} \\
\hline \multirow{3}{*}{3} & & $31-45$ year & $15(33.3 \%)$ & $30(66.7 \%)$ & $45(100 \%)$ & \\
\hline & & 46-60 year & $25(33.8 \%)$ & $49(66.2 \%)$ & $74(100 \%)$ & \\
\hline & & $>60$ year & $8(33.3 \%)$ & $16(66.7 \%)$ & $24(100 \%)$ & \\
\hline \multirow{5}{*}{4} & \multirow{5}{*}{ Education } & No & $3(21.4 \%)$ & $11(78.6 \%)$ & $14(100 \%)$ & \multirow{5}{*}{0.267} \\
\hline & & elementary & $14(28.0 \%)$ & $36(72.0 \%)$ & $50(100 \%)$ & \\
\hline & & Yunior high school & $5(21.7 \%)$ & $18(78.3 \%)$ & $23(100 \%)$ & \\
\hline & & Senior high school & $21(44.7 \%)$ & $26(55.3 \%)$ & $47(100 \%)$ & \\
\hline & & University & $10(33.3 \%)$ & $15(66.7 \%)$ & $9(100 \%)$ & \\
\hline \multirow{4}{*}{5} & \multirow{4}{*}{ Job } & Military, police or Government employees & $13(52.0 \%)$ & $12(48 \%)$ & $25(100 \%)$ & \multirow{4}{*}{0.085} \\
\hline & & Private and self-employed & $9(36.0 \%)$ & $16(64.0 \%)$ & $25(100 \%)$ & \\
\hline & & Farmers, laborers, and artisans & $15(23.8 \%)$ & $48(76.2 \%)$ & $63(100 \%)$ & \\
\hline & & No job & $16(34.8 \%)$ & $30(65.2 \%)$ & $46(100 \%)$ & \\
\hline \multirow{3}{*}{6} & \multirow{3}{*}{ Assurance } & No & $1(5.3 \%)$ & $18(94.7 \%)$ & $19(100 \%)$ & \multirow{3}{*}{0.001} \\
\hline & & Private health Assurance & $19(54.3 \%)$ & $16(45.7 \%)$ & $35(100 \%)$ & \\
\hline & & Public health assurance & $33(31.4 \%)$ & $72(68.6 \%)$ & $105(100 \%)$ & \\
\hline \multirow{2}{*}{7} & Marital & Yes & $52(33.5 \%)$ & $103(66.5 \%)$ & $155(100 \%)$ & \multirow{2}{*}{0.593} \\
\hline & status & No & $1(25.0 \%)$ & $3(75.0 \%)$ & $4(100 \%)$ & \\
\hline
\end{tabular}

Most of the research subjects were between 46-60 years old $(50.3 \%)$, followed by the general group $31-45$ years $(27 \%)$. $>60$ years $(18.2 \%)$ and $16-30$ years $(7.4 \%)$. The difference in the distribution of research subjects based on age groups between ESRD patients and not ESRD was not different ( $>>0.05)$. 


\subsection{Overview of respondents' clinical conditions}

An overview of clinical and laboratory conditions is presented in Table 2. The table shows that the average $\mathrm{Hb}$, erythrocytes, leukocytes, and hematocrit levels of the ESRD group were lower than the control group $(p<0.05)$. Blood glucose, urea, and creatinine levels in the ESRD group were higher than the control group $(\mathrm{p}<0.05)$. Anemia is one of the distinguishing factors in handling ESRD patients [24].

Table 2. Clinical and laboratory conditions of ESRD patients

\begin{tabular}{ccccc}
\hline No & Respondents characteristic & Cases & Control & $\mathrm{p}$ \\
\hline 1 & Age & $48.34 \pm 11.15$ & $48.18 \pm 11.32$ & 0.962 \\
2 & Body weight & $57.23 \pm 8.06$ & $57.62 \pm 9.01$ & 0.787 \\
3 & BMI & $22.21 \pm 2.79$ & $22.33 \pm 3.27$ & 0.809 \\
4 & Hb level & $8.24 \pm 1.46$ & $12.93 \pm 1.81$ & $0.000^{*}$ \\
5 & Eritrocytes & $2.89 \pm 0.56$ & $4.58 \pm 0.58$ & $0.000^{*}$ \\
6 & Leucocytes & $7.08 \pm 2.06$ & $9.24 \pm 3.21$ & $0.000^{*}$ \\
7 & Thrombocytes & $242.26 \pm 65.23$ & $249.33 \pm 68.17$ & 0.533 \\
8 & Haematocrit & $23.54 \pm 2.90$ & $38.73 \pm 5.62$ & $0.000^{*}$ \\
9 & Blood glucose ad random (RBG) & $120.87 \pm 23.22$ & $107.72 \pm 13.87$ & $0.000^{*}$ \\
10 & hypertriglyseridemia & $118.46 \pm 56.18$ & $115.63 \pm 38.18$ & 0.742 \\
11 & Ureum level & $155.76 \pm 42.81$ & $21.65 \pm 7.82$ & $0.000^{*}$ \\
12 & Creatinine level & $8.83 \pm 2.97$ & $0.75 \pm 0.24$ & $0.000^{*}$ \\
13 & Glomerular filtration rate (GFR) & $5.81 \pm 2.97$ & $104.89 \pm 20.05$ & $0.000^{*}$ \\
\hline Note:* $=$ p $<0.05$ & & &
\end{tabular}

\subsection{Bivariate analysis of clinical and biological conditions with ESRD events}

The relationship of the biological and clinical characteristics of respondents with the incidence of ESRD is presented in Table 3. This table reveals that the incidence of ESRD is related to clinical conditions. Anemia is related to the incidence of ESRD Anemic conditions ( $\mathrm{Hb}<12 \mathrm{mg} \%)$ have a 37x ESRD risk compared to not anemic. RBG status $>120 \mathrm{mg} / \mathrm{ml}$ increases the risk of ESRD $2.79 \mathrm{x} \quad(\mathrm{p}<0.05)$. The condition of hypertriglyceridemia (TG level $>200 \mathrm{mg} / \mathrm{dl}$ ) increases the risk of ESRD 5.42x. The body mass index is not related to the incidence of ESRD. The results of the study are in line with other studies [23, 25].

Table 3. Relationship between the clinical characteristic (BMI, haemoglobin, RBG, and triglycerides)

\begin{tabular}{|c|c|c|c|c|c|c|}
\hline Clinical biology c & cteristic & Cases & controlled & Total & OR; CI;95\% & $P$ \\
\hline \multirow{4}{*}{ BMI classification } & Lean & $6(31.6 \%)$ & $13(68.4 \%)$ & $19(100 \%)$ & 1 & 0.856 \\
\hline & Normal & $37(35.6 \%)$ & $67(64.4 \%)$ & $104(100 \%)$ & $0.84(.29-2.38)$ & 0.737 \\
\hline & Fat & $6(28.6 \%)$ & $15(71.4 \%)$ & $21(100 \%)$ & $1.15(.29-4.47)$ & 0.836 \\
\hline & Obesity & $4(26.7 \%)$ & $11(73.3 \%)$ & $15(100 \%)$ & $1.27(.28-5.68)$ & 0.755 \\
\hline \multirow{2}{*}{ Hb level } & $<12$ & $51(54.3 \%)$ & $43(45.7 \%)$ & $94(100 \%)$ & \multirow{2}{*}{37 (8.63-161.68) } & \multirow{2}{*}{0.000} \\
\hline & $>=12$ & $2(3.1 \%)$ & $63(96.9 \%)$ & $65(100 \%)$ & & \\
\hline \multirow{2}{*}{ RBG } & $>120$ & $21(51.2 \%)$ & $20(48.8 \%)$ & $41(100 \%)$ & \multirow{2}{*}{$2.79(1.337-5.817)$} & \multirow{2}{*}{0.005} \\
\hline & $<=120$ & $32(27.4 \%)$ & $85(72.6 \%)$ & $117(100 \%)$ & & \\
\hline \multirow{2}{*}{ Hypertrilgeridemia } & $>200$ & $5(71.4 \%)$ & $2(28.6 \%)$ & $7(100 \%)$ & \multirow{2}{*}{$5.42(1.014-8.922)$} & \multirow{2}{*}{0.042} \\
\hline & $<=200$ & $48(31.6 \%)$ & $104(68.4 \%)$ & $152(100 \%)$ & & \\
\hline
\end{tabular}

\subsection{Bivariate analysis relationship between respondent's history and ESRD events}

Pre-morbid conditions that increase the risk of ESRD events are presented in Table 4. The results of the study showed that some history of the disease was related to the incidence of ESRD. History of DM, hypertension, hypercholesterolemia has been shown to increase the incidence of ESRD. The family history of the ESRD is also related to the prevalence of ESRD. Opportunities for ESRD events in respondents with a history of DM 34x than without a history of DM. Opportunities for ESRD events in respondents with a history of hypertension 8x than respondents did not have a history of hypertension. Family history of ESRD pain is 8.6 times more than families without a history of ESRD. The results of the study are in accordance with the results of previous studies [1, 26], except obesity. Diabetes mellitus (DM), hypertension (HTN), obesity and cardiovascular disease have attributed to the rapid rise in the incidence of CKD in most parts of the world, especially in developing countries [1]. 
Table 4. Relationship of previous illness history with ESRD events in respondents

\begin{tabular}{ccccccc}
\hline Illness history & & Cases & controlled & Total & OR, CI 95\% & p \\
\hline \multirow{2}{*}{ DM } & Yes & $21(91.3 \%)$ & $2(8.7 \%)$ & $23(100 \%)$ & $34(7.58-153.48)$ & 0.000 \\
& no & $32(23.5 \%$ & $104(76.5 \%)$ & $136(100 \%)$ & & \\
Hypertension & Yes & $37(62.7 \%)$ & $22(37.3 \%)$ & $59(100 \%)$ & $8(4.17-18.71)$ & 0.000 \\
& no & $16(16.0 \%)$ & $84(84.0 \%)$ & $100(100 \%)$ & & \\
\multirow{2}{*}{ Hipercholesterolemia } & Ya & $18(58 \%)$ & $13(42 \%)$ & $31(100)$ & $3(1.6-8.29)$ & 0.001 \\
& Tidak & $35(27 \%)$ & $93(73 \%)$ & $128(100 \%)$ & & \\
\multirow{2}{*}{ ESRD in family } & Yes & $4(80 \%)$ & $1(20 \%)$ & $5(100 \%)$ & $8(0.93-78.71)$ & 0.043 \\
& No & $49(31.8 \%)$ & $105(68.2 \%)$ & $154(100 \%)$ & & \\
\hline
\end{tabular}

\section{CONCLUSION}

The clinical conditions of hyperglycemia, hypertriglyceridemia, and anemia are associated with the incidence of ESRD. History of diabetes, hypercholesterolemia, hypertension, and family history with ESRD are also related to the prevalence of ESRD.

\section{ACKNOWLEDGEMENTS}

Thank you to UMY that provided research funding through a multidisciplinary research grant at Research Institute and community service.

\section{REFERENCES}

[1] Epidemiology of Chronic Kidney Disease in Pakistan: A Global and Regional Perspective, Saudi J Kidney Dis Transpl 2018;29(6):1441-1451 @ Saudi Center for Organ Transplantation, 2018.

[2] Mihardja L, Delima D, Massie RGA, Karyana M, Nugroho P, Yunir E. 2018. Prevalence of kidney dysfunction in diabetes mellitus and associated risk factors among productive age Indonesian. J Diabetes Metab Disord. Mar 27;17(1):53-61. doi: 10.1007/s40200-018-0338-6, 2018.

[3] Fox, C.S., Gona, P., Larson, M.G., Selhub,J., Tofler, G., A Multi-Marker Approach to Predict Incident CKD and Microalbuminuria, J Am Soc Nephrol, 21: 2143-2149, 2010.

[4] Rhee CM, and Kovesdy CP. Epidemiology: Spotlight on CKD deaths-increasing mortality worldwide. Nat Rev Nephrol. 2015 Apr;11(4):199-200. doi: 10.1038/nrneph.2015.25. Epub 2015 Mar 3, 2015.

[5] Schoolwerth, A.C., Engelgau, M.M., Hostetter, T.H., Rufo, K.H., McClelan, W.M., Chronic kidney disease a publik health problem that needs a public health action plan, Prevention Chronic Disease, 3(2):1-5, 2006.

[6] Prodjosudjadi. W., Incidence, Prevalence, Treatment and Cost of End-Stage Renal Disease In Indonesia, Ethn Dis. ;16[suppl 2]:S2-14-S2-16), 2006.

[7] Bakri, S., Early detection and efforts to prevent progression in chronic kidney failure, Jurnal Medika Nusantara, 26(3):36-39, 2005.

[8] Trihono PP, Rhodia L, Karyanti MR, Kidney Disease Profiles Among Adolescents In Indonesia. Acta Med Indonesia. 2018 Oct;50(4):283-290, 2018.

[9] Landray, M.J., Emberson, J.R., Blackwell, L., Dasgupta, T., Zakeri, R., Morgan, M.D., Prediction of ESRD and death among people with CKD the chronic renal impairment in Birmingham (CRIB) prospective cohort study, American Journal of Kidney Disease, 56,6, 1082 -94, 2010.

[10] Dalrymple, LS. and Go, AS., Epidemiology of acute infections among patients with chronic kidney disease, J. American society of nephrology, 2008.

[11] Go, A., Yang, J., Ackersen, L.M., Lepper, K., Robbins, B.M., Hemoglobin level, chronic kidney disease and the risk of death and hospitalization in adults with chronic heart failure, circulation, 113, $2713-2723,2006$.

[12] Kuo, H.W., Tsai, S.S., Tiao, M.M., Yang, C.Y., Epidemiological features of CKD in Taiwan, Am J Kidney Dis, 49:46-55, 2007.

[13] Stevens, L.A., Coresh, J., Greene, T., Levey, A.S., Assesing kidney function-measured and estimated glomerular filtration rate, NEJM, 354:2473-83

[14] Cohen, SD., Patel, SS., Khetpal, P. Peterson, RA., Kimmel, PL., Pain, sleep disturbance, and quality of life in patients with chronic kidney disease, Clin J Am Soc nephrol 2: 919-925, 2007.

[15] Ozieh MN, Bishu KG, Dismuke CE, Egede LE. Trends in healthcare expenditure in United States adults with chronic kidney disease: 2002-2011. BMC Health Serv Res. 2017 May 22;17(1):368. doi: 10.1186/s12913-017-2303-3, 2017.

[16] Dodd R, Palagyi A, Guild L, Jha V, Jan S. 2018. The impact of out-of-pocket costs on treatment commencement and adherence in chronic kidney disease: a systematic review. Health Policy Plan. Nov 1;33(9):1047-1054. doi: 10.1093/heapol/czy081, 2018. 
[17] Hidayati, T., The relation of Phamily Apgar score, quality of care, comorbidity and smoker habitual to quality of life ESRD patients in PKU Muhamadiyah Yogyakarta Hospital, FKIK UMY, 2009.

[18] Chen, L., Yang, T., Lu, D.-W., Zhao, H., Feng, Y.-L., Chen, H., ... Zhao, Y.-Y. Central role of dysregulation of TGF$\beta /$ Smad in CKD progression and potential targets of its treatment. Biomedicine \& Pharmacotherapy, 101, 670-681. doi:10.1016/j.biopha.2018.02.090, 2018.

[19] Hazzan AD, Halinski C, Agoritsas S, Fishbane S, DeVita MV. Epidemiology and Challenges to the Management of Advanced CKD. Adv Chronic Kidney Dis. 2016 Jul;23(4):217-21. doi: 10.1053/j.ackd.2016.04.005, 2016.

[20] Major RW, Brown C, Shepherd D, Rogers S, Pickering W, Warwick GL, Barber S, Ashra NB, Morris T, Brunskill NJ.2019.T he Primary-Secondary Care Partnership to Improve Outcomes in Chronic Kidney Disease (PSP-CKD) Study: A Cluster Randomized Trial in Primary Care. J Am Soc Nephrol. May 16. pii: ASN.2018101042. doi: 10.1681/ASN.2018101042, 2019.

[21] Small C, Kramer HJ, Griffin KA3, Vellanki K, Leehey DJ, Bansal VK, Markossian TW. Non-dialysis dependent chronic kidney disease is associated with high total and out-of-pocket healthcare expenditures. BMC Nephrol. 2017 Jan 5;18(1):3. doi: 10.1186/s12882-016-0432-2, 2017.

[22] Retnakaran, R., Cull, C.A., Thorn, K.I., Adler, A.I., Holman, R.R. Risk factors for renal dysfunction in type type 2 Diabetes; Diabetes;55:1832-9, 2006.

[23] Miyazawa, H., Ookawara, S, Ito, K., Ueda, Y.,Yanai, K., Ishii, H., Mutsuyoshi, Y., Kitano, T., Shindo, M., Aomatsu, A., Hirai, K., Hoshino, T., Morishita, Y. Association of cerebral oxygenation with estimated glomerular filtration rate and cognitive function in chronic kidney disease patients without dialysis therapy, PLoS One. 2018; 13(6): e0199366, 2018.

[24] Kazory, A., and Ross, E.A., Anemia: The Point of Convergence or divergence for Kidney Disease and Heart Failure?, Journal of the American College of Cardiology, 53, . 8, 639-47, 2009.

[25] Hallan, S.I., Coresh, J., Astor, B.C., Åsberg, A., Powe, N.R., Romundstad, S., Hallan, H.A., Holme, J., International Comparison of the Relationship of Chronic Kidney Disease Prevalence and ESRD Risk, J Am Soc Nephrol 17: 2275 2284, 2006.

[26] Agarwal, R., Andersens, M.J., Correlates of systolic hypertension in patients with chronic kidney disease, Hypertension. J Am Soc Nephrol, 46: 514-520, 2005. 